
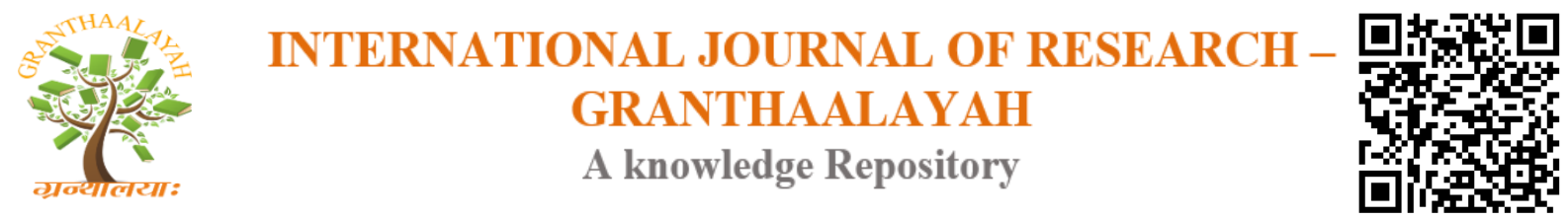

Science

\title{
THE METHODOLOGY OF ASSESSING CALL IN IMPROVING LISTENING SKILLS AMONG ENGINEERING COLLEGE STUDENTS
}

\author{
M.Anand *1 \\ ${ }^{*}$ Ph.D. Research Scholar, Ramco Institute of Technology, India
}

\begin{abstract}
In the recent trend and development, the scope for the study in improving language skills through CALL plays an important role in building a bridge between language and technology, the conceptual details of how computers could be used to learn language can be something inimitable and different. In this study, the researcher tries to find out The Methodology of Assessing CALL in Improving Listening Skills among Engineering College Students, Virudhunagar.
\end{abstract}

Keywords: Methodology; Technology; Inimitable; Hypotheses and Statistical.

Cite This Article: M.Anand. (2017). "THE METHODOLOGY OF ASSESSING CALL IN IMPROVING LISTENING SKILLS AMONG ENGINEERING COLLEGE STUDENTS." International Journal of Research - Granthaalayah, 5(8:SE), 8-13. https:// doi.org/10.29121/granthaalayah.v5.i8(SE).2017.2239.

\section{Introduction}

In the recent trend and development, the scope for the study in improving language skills through CALL plays an important role in building a bridge between language and technology, the conceptual details of how computers could be used to learn language can be something inimitable and different. In trying to explain the Methodology in comparison of two different engineering college students from different districts, the plan, procedure and the assessment of CALL based study are discussed in this chapter. It contains the assumptions of the study, hypotheses of the study, sample of the study, research design of the study, structure of the experiment, selection of the experimental and control group, development of research tool, administration of the tool and statistical techniques employed for the data analysis.

\section{Assumptions of the Study}

The following are the assumptions for the present study

- There are so many tasks in developing listening skills in English.

- Depending upon the objectives, the comprehension skills can be categorized.

- Task plays a vital role in developing listening skills among students. 
- Task based activities can be used to promote various skills in developing listening skills in English.

- The effectiveness of the CALL-based approach can be measured.

- The effectiveness of CALL based approach can be compared with other approaches

\section{Hypotheses of the Study}

The following are the hypotheses formulated for the present study.

\section{Major Hypothesis}

- There may not be any significant difference between Computer Assisted Language Learning and Traditional Method of Teaching in developing listening skills in English among the engineering students of Madurai

- There may not be any significant difference between Computer Assisted Language Learning and Traditional Method of Teaching in developing listening skills in English among the engineering students of Virudhunagar

- There may not be any significant difference between the engineering students of Madurai and Virudhunagar in developing listening skills in English through Computer Assisted Language Learning

\section{Specific Hypothesis}

- There may not be any significant difference between the pre-test mean values of control group and experimental group of engineering students belonging to Madurai and Virudhunagar in developing listening skills in English.

- There may be any significant difference between the pre-test and the post-test mean values of control group of engineering students belonging to Madurai and Virudhunagar in developing listening skills in English.

- There may be any significant difference between the pre-test and the post-test mean values of experimental group of engineering students belonging to Madurai and Virudhunagar in developing listening skills in English.

- There may not be any significant difference between Madurai and Virudhunagar engineering students in developing listening skills in English in pre-test.

- There may not be any significant difference between Madurai and Virudhunagar engineering students in developing listening skills in English in post-test.

- There may not be any significant difference between male students and female engineering students mean values belonging to both the districts in developing listening skills in English in pre-test.

- There may not be any significant difference between male students and female engineering students mean values belonging to both the districts in developing listening skills in English in post-test.

- There may not be any significant difference between reading habit in mother tongue and in English students mean values belonging to both the districts in developing listening skills in English in pre- test.

- There may not be any significant difference between listening habit in mother tongue and in English students mean values belonging to both the districts in developing listening skills in English in post-test. 
- There may not be any significant difference between rural students and urban engineering students mean values belonging to both the districts in developing listening skills in English in pre-test.

- There may not be any significant difference between rural students and urban engineering students mean values belonging to both the districts in developing listening skills in English in post-test.

\section{Sampling Plan for the Study}

In sampling for study, the institutions of mainstream education were taken into consideration. As the survey was conducted on the intermediate students, colleges were chosen for the investigation. Since the curriculum and syllabi in the intermediate level are the same which represents the whole country. So, two district and two colleges of the mainstream education under that district were considered as representatives of the system.

Considering the above argument and convenience in conducting the present study, only Virudhunagar district is chosen for collecting data. It is an area of cluster sampling. Since the study is a comparative study between Madurai students and Virudhunagar students at the college level, the sample was taken from both students. The samples of the present study have been collected from engineering college students of Madurai and Rajapalayam, Tamilnadu. A total of 40 students of Virudhunagar and another total of 40 students of Madurai were selected for the present study. Based on their previous examination scores in English, the samples have been selected.

Thus the control group and experimental groups in Madurai as well as in Virudhunagar were formed.

\section{Research Tool}

For the present study, the investigator developed and validated an achievement test to collect data from students. The main purpose of the Achievement test for the pre-test and post-test was to know the entry behavior and terminal behavior of the students. The difference between pretest and post-test will show the effectiveness of the Suggestopedia approach in developing listening skills in English at college level. To assess the effectiveness of activities and to compare the achievement of graduate students taught through the activities and exercises (experimental group) with that of the control group, an achievement test was conducted. This test was used to assess the achievement in various skills of learning listening skills in English.

\section{Questionnaire}

Most of the research carried out for solving business problems requires primary data. The researcher should collect data through questionnaires or interview schedules and process the same, so as to provide solution to the identified problem. A questionnaire is a formalized framework consisting of a set of questions and scales designed to generate primary raw data. It is formulated written set of questions to which the respondents record their answers. The answers are mostly chosen by a respondent from within the closely defined alternatives. The 
questionnaires can be administered personally, mailed to the respondents or electrically distributed.

\section{Administration of Control and Experimental Group}

The experimental group students were taught listening skill in English through activities for a period of 60 working days at the rate of one and half hours per day.

The approach influences through processes and behavioral patterns of learners to a certain extent. It is also known that this task based approach is the learner's favorite media of learning and entertainment. Learners derive pleasure by using task based approach. This approach could provide pleasurable experiences which have been utilized for triggering off the learning of skills. For each skill, the investigator has prepared suitable activity, and while preparing the exercise, the psychology of the students had been taken into account. Therefore, the approach combines humour, suspense, thrill and variety. In certain activities, the words and sentences were not arranged in a proper sequence. These things were done in order to bring the principles of information gap and information transfer and thereby to generate real comprehension in the classroom.

In the experimental group itself the students were given activities in which part of the information is hidden. The students were asked to guess the hidden information by way of indulging in asking questions and getting clarification. This is one of the methods to generate real situations in the classroom. Here the principle of information gap is used. After each and every activity was over, the investigator gave more examples and asked comprehension questions.

The investigator also provided activities based on the principle of information transfer. Thus the communication between two groups of students is generated. For the first group, certain information relating to a topic is given. For the second group, different information relating to the same topic is given. Here, the peer group interaction in the items of questioning, answering and clarifying doubts was facilitated and a conductive atmosphere without fear, anxiety and stress was created. This arouses the spirit of enquiry in the students. In fact all these facilitated the effective skills of students in English and its grammar. In this process, the investigator acted as guide and facilitator to the students to develop the various skills of listening skills in English Language.

In the whole experimentation, the students were made active partners in giving and receiving information from other members. Likewise, to promote the skills of finding and correcting errors in English, students were asked to prepare a dialogue using the language function learnt while they exchanged and discussed. In this process, the students got their mistakes corrected with the help of the peer group members or they were rewarded for their correct responses.

For the control group students, language functions and various skills in developing listening skill in English were taught orally using traditional method. In traditional method, the investigator teacher simply explains the ideas found in the passage by way of using synonyms or definitions. In the traditional method, mechanical drill was given importance. Individual, group and choral 
drilling activities in language acquisition were provided in a mechanical way. This process lasted for 60 days as in the case of the experimental group.

\section{Statistical Analysis}

The data collected from students were analyzed at descriptive and differential level. The following statistical techniques were employed for the analysis and interpretation of the collected data.

1) Mean and Standard Deviation

2) Product moment correlation technique

3) t-test to find out the significance of difference between mean scores.

\section{Methods of Analysis}

The method of analyzing is very important in any research project. In certain projects testframing, test and item-analysis involve a lot of work and scoring and final analysis may be comparatively easy. In the present instance framing the test took a great deal of time. So, error analysis was not affected. The first stage of analysis involved finding out if every test item was answered correctly or not. The total number of correct responses and wrong responses were found out.

The data thus collected were used to make a comparative study between the variables such as Nationality, Gender and Locale among the engineering students of Madurai and Virudhunagar to find out the effectiveness of CALL based instruction.

In this Methodological study, the investigator has made an attempt to find out the use of Computer Assisted Language Learning in improving listening skill in English among engineering college students.

\section{References}

[1] Carrell, P. L. (2007). Note taking strategies and their relationship to performance on listening comprehension and communicative assessment tasks (TOEFL Monograph Series No. RS-35). Princeton, NJ: ETS. Retrieved from https://www.ets.org/Media/Research/pdf/RR-07-01.pdf

[2] Carroll, J. B. (1980). Testing communicative performance: an interim study. Oxford: Pergamon Press Ltd. Print.

[3] Doughty, C., \& Williams, J. (1998). Focus on form in classroom second language acquisition. Cambridge: Cambridge University Press. Print.

[4] Ellis, N. C., \& Sinclair, B. (1996). Working memory in the acquisition of vocabulary and syntax: putting language in good order. The Quarterly Journal of Experimental Psychology, 49a. Print.

[5] Golden, S. A. R. (2011). Problems and Prospectus of Distance Education. Quality Enhancement In Distance Education For Life Long Learning, 1(1), 343-344.

[6] Golden, S. A. R. (2017). Attitude of Students and Teachers towards E-Learning-An Analysis. Recent Research in Social Science \& Humanities, 1, 5-10.

[7] Golden, S. A. R. (2017). Recent Research in Social Sciences \& Humanities. EduPedia Publications (P) Ltd.

[8] Hamouda, A. (2012). Listening comprehension problems - voices from the Classroom. Language in India, 12(8), 1-49. Retrieved from 
http://www.languageinindia.com/aug2012/arafatlisteningproblemsfinal.pdf

[9] McLaughlin, B., \& Heredia, R. (1996). Information-processing approaches to research on second language acquisition and use. In W. Ritchie \& T. Bhatia (Eds.), Handbook of Second Language Acquisition. San Diego, CA: Academic Press. Print.

[10] Regi, S. B., \& Golden, S. A. R. (2014). A Study On Educational Loan Availed By Students In Trichy City. Journal Of International Academic Research For Multidisciplinary (Jiarm), 2 (1). 